\title{
TARIFF AND REGULATORY BARRIERS TO FREE TRADE IN EASTERN PARTNERSHIP COUNTRIES
}

\author{
๑2019 ISMAYIL Z. N.
}

UDC 338.984

JEL: F13

\section{Ismayil Z. N. Tariff and Regulatory Barriers to Free Trade in Eastern Partnership Countries}

The purpose of this article is to identify and compare the tariff and regulatory barriers for the free trade in Eastern Partnership counties (Ukraine, Moldova, Belarus, Georgia, Azerbaijan, and Armenia). Free trade as a concept requires policy reforms toward the reduction of tariffs and for quantitative restrictions for efficacious trade liberalization. UNSTAD reports that, two factors dominantly influenced economic performance in the transition economies that are parts of the CIS countries: the economic integration with and dependence on Russia, the importance of commodities, and oil for the prosperity. Doing Business 2020 suggests that Belarus became a leader with regard to ease of cross-border trading. The country is ranked 24th among 190 economies for ease of trading across borders. A few years before Georgia was a leading country in terms of cross-border trading, but now this country lags behind Belarus, Moldova, and Armenia. Cross-border trading with Azerbaijan and Ukraine is much more difficult. Both countries have longer and more costly procedures with more documentation required than other Eastern Partnership countries.

Keywords: export diversification, free trade, cross-border trading, Eastern Partnership, non-oil sector.

DOI: $h$ ttps://doi.org/10.32983/2222-4459-2019-12-63-69

Fig.: 3. Tbl.: 5. Bibl.: 15.

Ismayil Zohrab N. - Applicant, Simon Kuznets Kharkiv National University of Economics (9a Nauky Ave., Kharkiv, 61166, Ukraine)

E-mail: zokhrab.ismayil@hneu.net

УДК 338.984

JEL: F13

Ісмаїл 3. Н. Тарифні та регуляторні бар'єри для свободи торгівлі у країнах Східного партнерства

Метою цієї статті є визначення та порівняння тарифних та регуляторних бар'єрів для свободи торгівлі у країнах Східного партнерства (Україна, Молдова, Білорусь, Грузія, Азербайджан та Вірменія). Вільна торгівля як концепція вимагає реформ політики щодо зниження тарифів та кількісних обмежень для ефективної лібералізації торгівлі. Відповідно до звіту UNSTAD про торгівлю та розвиток за 2019 рік, два фактори домінуюче впливали на економічні показники в країнах з перехідною економікою, що входять до країн СНД: економічна інтеграція та залежність від Росії, важливість товарів та нафти для процвітання. Індекс Doing Business 2020 свідчить про те, що Білорусь стала лідером щодо простоти транскордонних торгів. Країна займає 24 місче серед 190 економік за легкістю торгівлі через кордон. Кілька років до чього Грузія була провідною країною за транскордонною торгівлею, але зараз ия країна відстає від Білорусі, Молдови та Вірменії. Транскордонна торгівля з Азербайджаном та Україною набагато складніша. Обидві країни мають більш тривалі та затратні процедури, які вимагають багато документації, ніж інші країни Східного партнерства. Ключові слова: диверсифікація експорту, вільна торгівля, транскордонна торгівля, Східне партнерство, ненафтовий сектор.

Рис.: 3. Табл.: 5. Бібл.: 15

Ісмаїл Зохраб Нейман огли - здобувач, Харківський начіональний економічний університет ім. С. Кузнеия (просп. Науки, 9а, Харків, 61166, Україна) E-mail: zokhrab.ismayil@hneu.net
УДК 338.984 JEL: F13

Исмаил 3. Н. Тарифные и нормативные барьеры для свободы торговли в странах Восточного партнерства

Целью данной статьи является выявление и сравнение тарифных и нормативных барьеров для свободы торговли в странах Восточного партнерства (Украина, Молдова, Беларусь, Грузия, Азербайджан и Армения). Свободная торговля как концепция требует политических реформ в направлении снижения тарифов и количественных ограничений для эфффективной либерализации торговли. Согласно Докладу ЮНСТАД о торговле и развитии за 2019 год, два фактора в значительной степени повлияли на экономические показатели в странах с переходной экономикой, которые являются частью стран СНГ: экономическая интеграция и зависимость от России, важность сырьевых товаров и нефрти для процветания. Индекс Doing Business 2020 свидетельствует, что Беларусь стала лидером в отношении легкости трансграничной торговли. Страна занимает 24-е место среди 190 стран по легкости торговли через границу. За несколько лет до этого Грузия была ведущей страной с точки зрения трансграничной торговли, но теперь эта страна отстает от Беларуси, Молдовы и Армении. Трансграничная торговля с Азербайджаном и Украиной намного сложнее. Обе страны имеют более длительные и дорогостоящие процедуры, требующие много документации, чем другие страны Восточного партнерства. Ключевые слова: диверсификация экспорта, свободная торговля, трансграничная торговля, Восточное партнерство, ненефтяной сектор. Рис.: 3. Табл.: 5. Библ.: 15.

Исмаил Зохраб Нейман оглы - соискатель, Харьковский национальный экономический университет им. С. Кузнеца (просп. Науки, 9а, Харьков, 61166, Украина)

E-mail: zokhrab.ismayil@hneu.net
$\mathrm{F}$ ree trade as a concept requires policy reforms toward the reduction of tariffs and quantitative restrictions for efficacious trade liberalization. $\mathrm{Na}$ tions are increasingly convinced of the need for trade liberalization as a result of several rounds of trade policy reforms aimed primarily at the reduction of tariffs and quantitative restrictions. Given the interrelation and interdependence between trade and economic growth, high dependence on crude oil also can lead to discrediting the economic growth of the country.
According to the Trade and Development Report of UNSTAD 2019, two factors dominantly influenced economic performance the transition economies that are members of the Commonwealth of Independent States. First, the economic integration with and dependence on Russia through trade and remittance earnings of these countries. And, second, the importance of commodities and oil in the economies of particular countries, making commodity trade trends and price movements a crucial determinant of their performance [1]. 
D espite the tensions with Russia, international trade of Ukraine has been increasing since 2016. In 2018, the total volume of exports was $\$ 47.3$ billion, which is $9 \%$ more than the indicator of 2017 . As the imports ( $\$ 57.2$ billion) grew by $15.7 \%$, the international trade deficit also increased from $\$ 6$ billion to $\$ 9.9$ billion during the reporting period.

More positive trends are observed in international trade of Azerbaijan due to an increase in prices in the crude oil market. The overall amount of exports amounted to $\$ 19.5$ billion in 2018 , which is $27 \%$ more than that for the previous year.

Georgia succeeded in international trade in 2018 as well. International trade of the country demonstrated a stable positive trend: its exports totaled $\$ 3.4$ billion (with an 22.7\% increase). However, after 2016, it started shrinking because of the crises in Azerbaijan, Russia, and Turkey, which are the leading trade partners of Georgia. As a concequence, Georgia has the most significant international trade deficit, which was $\$ 5.2$ billion in 2017 and $\$ 5.8$ billion in 2018 .

It is worth studying the trends in international trade of Ukraine with Azerbaijan and Georgia. According to the World Integrated Trade Solution 2018, the volume of international trade turnover of Ukraine was $\$ 104.5$ billion, with its imports at $\$ 57.2$ billion and exports at $\$ 47.3$ billion. During 2018, it cooperated with 202 countries, and its international trade balance was negative, at $\$ 9.9$ billion [2].
$T b l$. 1 demonstrates the basket of main exports from Ukraine, which includes agricultural products, ores and metals, and manufactured items. The analysis of the commodity structure of exports suggests that Ukraine's exports are diversified. The county exported 3706 types of products to 193 countries.

According to UNCTAD, the exports of services of the country amounted to $\$ 15.8$ billion. The state started revitalizing export of services after the 2014-2015 tensions with Russia. However, the volume of service exports in 2018 is $30 \%$ less than in 2013. It is important to note that Ukraine achieved the maximal volume of service exports in 2013 (\$22.6 million).

Fig. 1 shows that Russia is still the leading export partner of Ukraine. The share of this country in exports of Ukraine shrank about four times compared to 2013.

According to the State Statistics Service, Russia lost this position in 2019, and Poland becomes the leading export partner of Ukraine [3].

A ccording to the World Integrated Trade Solution 2018, the volume of Azerbaijan's international trade turnover was $\$ 30.9$ billion, with exports at $\$ 19.5$ billion and imports at $\$ 11.5$ billion. It cooperated with 169 countries during the reporting year, and the international trade balance was positive at $\$ 8$ billion. $T b l .2$ demonstrates the level of the dependence of Azerbaijan on commodity exports.

Table 1

The main exported products of Ukraine at the HS 6 digit level in 2018

\begin{tabular}{|l|c|c|}
\hline \multicolumn{1}{|c|}{ Ukraine } & US\$ ths & Share in total \\
\hline Crude sunflower-seed and safflower oil and fractions thereof & $3,729,448.64$ & 7.88 \\
\hline Maize (excl. seed) & $3,496,683.04$ & 7.39 \\
\hline Spelt, common wheat and meslin & $2,993,967.70$ & 6.33 \\
\hline Agglomerated iron ores and concentrates & $1,611,065.11$ & 3.40 \\
\hline Ignition wiring sets and other wiring sets & $1,365,945.31$ & 2.89 \\
\hline Other products & $34,137,570.05$ & 72.12 \\
\hline Total & $\mathbf{4 7 , 3 3 4 , 6 7 9 . 8 5}$ & $\mathbf{1 0 0 . 0 0}$ \\
\hline
\end{tabular}

Source: World Integrated Trade Solution [2].

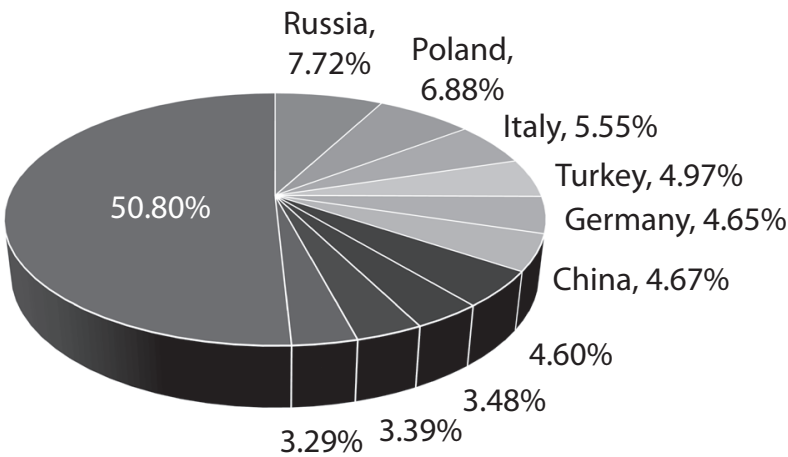

Fig. 1. The main export partners of Ukraine in 2018 [3] 
The main exported products of Azerbaijan at the HS 6 digit level in 2018

\begin{tabular}{|l|c|c|}
\hline \multicolumn{1}{|c|}{ Azerbaijan } & US\$ ths & Share in total \\
\hline Petroleum oils and oils obtained from bituminous materials & $15,719,482.37$ & 80.78 \\
\hline Natural gas in gaseous state & $1,499,385.84$ & 7.71 \\
\hline Petroleum oils, etc, (excl. crude); preparation & $520,600.68$ & 2.68 \\
\hline Tomatoes, fresh or chilled & $177,380.78$ & 0.91 \\
\hline Other fruit, fresh, nes & $132,384.51$ & 0.68 \\
\hline Other products & $1,410,398.33$ & 7.25 \\
\hline Total & $\mathbf{1 9 , 4 5 9 , 6 3 2 . 5 1}$ & $\mathbf{1 0 0 . 0 0}$ \\
\hline
\end{tabular}

Source: World Integrated Trade Solution [4].

The non-oil sector, including the private sector and individuals, accounted for only $8.8 \%$ of the total export volume in 2018. This share demonstrates that the non-oil private sector has not yet established itself as a critical player in the economic sphere in Azerbaijan.

Azerbaijan has a very high commodity and country concentration in international trade, especially in export operations. Table 2 also illustrates that the crude oil and natural gas heavily dominate Azerbaijan's exports, making up $88.5 \%$ of the total exports in 2018. The lack of export diversification is one of the main challenges for Azerbaijan's economy. According to the OECD-WTO report, Azerbaijan has the worst position in terms of export diversification in Eastern Europe and Asia [4].

Fig. 2 describes the main export partners of the country in Europe. In general, the European Union is one of Azerbaijan's leading trade partners.
As Georgia has a $\$ 2.2$ billion surplus in external trade of services, this factor somehow stabiles the international trade of the country.

Tbl. 3 demonstrates the top five goods in the commodity structure of Georgia's export. A share of the nonresource extractive industry products exceeds $25 \%$ of exports in 2018. The main changes at the top of the export basket are a decrease in the volume of hazelnuts and increase in that of cigarettes and other tobacco products for the last two years.

Fig. 3 shows the regional breakdown of Georgia's export basket. The main export partners of the country remain its close neighbors - Azerbaijan, Russia, and Armenia. According to the National Statistics Office, the main international trade partners of Georgia are Turkey, Russia, and Azerbaijan. Also, here we see an increase in the partnership with Russia. The international trade

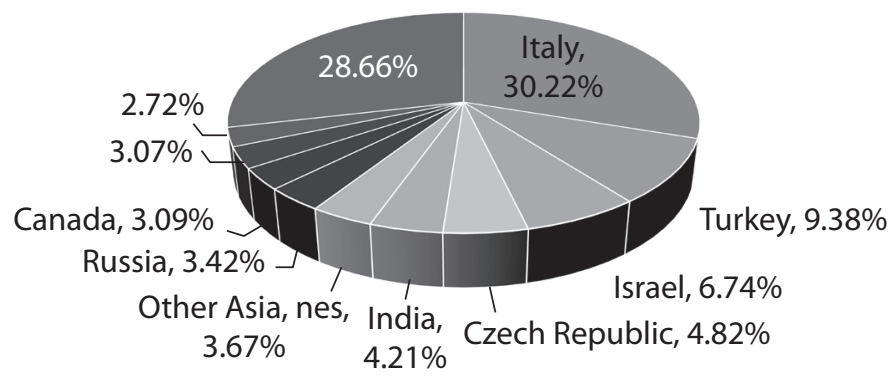

Fig. 2. The main export partners of Azerbaijan in 2018 [5]

The State Customs Committee of Azerbaijan reports that the trade turnover with the EU exceeded the share of the total trade by $41 \%$ in 2018 [5]. However, the tree Azerbaijan's key trading partners has not changed, and they are Italy, Turkey, and Russia.

According to the World Integrated Trade Solution 2018, the volume of Georgia's international trade turnover was $\$ 12.5$ billion, with its exports at $\$ 3.4$ billion and imports at $\$ 9.1$ billion. It cooperated with 133 countries during the reporting year, and the international trade balance was positive, at $\$ 5.8$ billion [6]. With this performance, it has the most significant international trade deficit among the Eastern Partnership countries. turnover between the two countries grew from $\$ 788$ million to $\$ 1.4$ billion in the period between 2015 and 2018 . A similar increase is observed in international trade turnover with Turkey but at a slower rate [7].

$\mathrm{F}$ urther, we will consider tariff and non-tariff barriers. In some cases, it is more expensive for countries to trade manufactured goods with their nextdoor neighbors than to trade with distant nations. Research by the World Bank has revealed that the two most important factors determining "thickness of borders" (in terms of trade costs) are maritime transport connectivity and logistics performance. Thus, poorer countries tend 
The main exported products of Georgia at the HS 6 digit level in 2018

\begin{tabular}{|l|c|c|}
\hline \multicolumn{1}{|c|}{ Georgia } & US\$ ths & Share in total \\
\hline Copper ores and concentrates & $504,456.49$ & 15.03 \\
\hline Ferro-silico-manganese & $345,619.12$ & 10.30 \\
\hline Automobiles with reciprocating piston engine & $225,636.14$ & 6.72 \\
\hline Wine (not sparkling); grape must with by alcohol & $192,456.49$ & 5.74 \\
\hline Cigarettes containing tobacco & $148,886.02$ & 4.44 \\
\hline Other products & $1,938,650.47$ & 57.77 \\
\hline Total & $\mathbf{3 , 3 5 5 , 7 0 4 . 7 3}$ & $\mathbf{1 0 0 . 0 0}$ \\
\hline
\end{tabular}

Source: World Integrated Trade Solution [6].

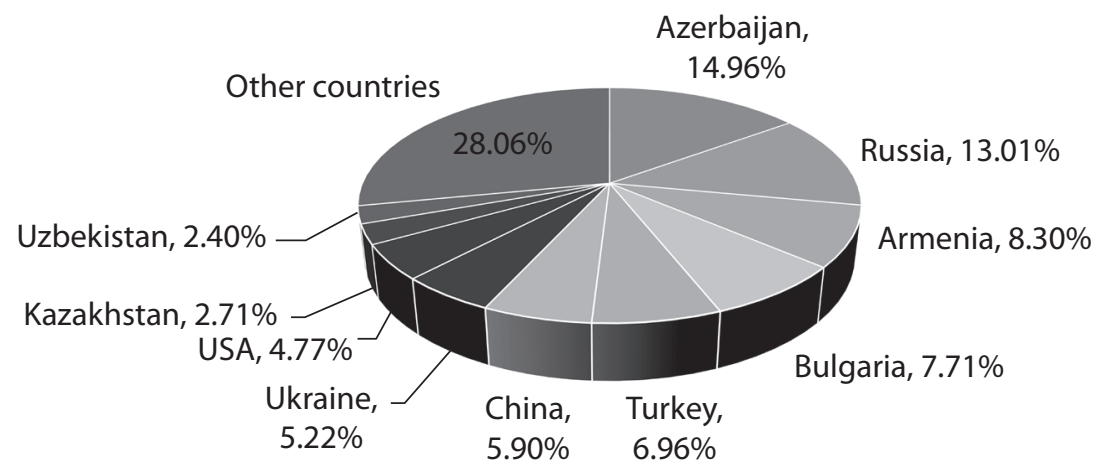

Fig. 3. The main export partners of Georgia in 2018 [7]

to have higher levels of trade costs than do more prosperous countries, in both manufactured and agricultural goods $[8$, p. 570]. This concept is a technical approach to the cost of trade, but we also have to take into account the potential of free business to diminish trade costs in the long run.

Trade regimes, customs, and trade finance are vital aspects of free trade. Specializing in goods and services where countries have relatively lower opportunity costs can encourage more benefits in terms of mutual trade turnover. Free trade enables countries to specialize in those goods for which they have a comparative advantage [9]. The existing literature defines free trade as "the importation and exportation of goods without any barriers in the form of tariffs, quotas, or other restrictions."

7 rade freedom is also considered as a composite measure of the absence of tariff and non-tariff barriers that affect imports and exports of goods and services. Trade freedom assessment is based on two inputs: (i) Trade-weighted average tariff rate; (ii) Non-tariff barriers (NTBs). Different imports entering a country can face separate tariffs. The weighted average tariff uses weights for each tariff based on the share of imports for each good. NTBs are used extensively across many goods and services and/or act to impede a significant amount of international trade effectively. The methodology of the Index of Economic Freedom includes these categories of NTBs:
+ "Quantity restrictions - import quotas, export limitations, voluntary export restraints, importexport embargoes and bans, countertrade, etc.

+ Price restrictions - antidumping duties, counterf vailing duties, border tax adjustments, variable levies/tariff rate quotas.

+ Regulatory restrictions - licensing, domestic content and mixing requirements.

+ Sanitary and phyto-sanitary standards (SPSs), safety and industrial standards regulations, packaging, labeling, and trademark regulations, advertising, and media regulations.

+ Investment restrictions - exchange and other fifi nancial controls.

+ Customs restrictions - advance deposit requiree ments, customs valuation procedures, customs classification procedures, customs clearance procedures.

+ Direct government intervention - subsidies and other aid, government industrial policy and regional development measures, government-financed research and other technology policies; national taxes and social insurance, competition policies, immigration policies, government procurement policies, state trading, government monopolies, and exclusive franchises" [10].

Partnership region, countries should commit to the gradual removal of customs duties, taxes and levies 
which have equivalent effect and quantitative restrictions in mutual trade; elimination of other barriers to a free transfer of goods and services; creation and development of an effective system of mutual settlements and payments on trade and other transactions; coordination of trade policy concerning other countries; coordination of economic policy to that extent to which this is necessary to achieve the regional objectives in the area of industry, agriculture, transport, finance, investment, social sphere, development of fair competition; promotion of cooperation of different branches, intra-branch and scientific, technical cooperation; harmonization and unification of legislation [11] (Tbl. 4).

Table 4

Trade freedom in Eastern Partnership countries

\begin{tabular}{|l|c|c|c|}
\hline Country & $\begin{array}{c}\text { Trade } \\
\text { freedom } \\
\text { score } \\
\text { (out of 100) }\end{array}$ & $\begin{array}{c}\text { Trade } \\
\text { freedom } \\
\text { rank } \\
\text { (out of 177) }\end{array}$ & $\begin{array}{c}\text { Trade- } \\
\text { weighted } \\
\text { average } \\
\text { tariff rate } \\
\text { (\%) }\end{array}$ \\
\hline Georgia & 88.80 & 6 & 0.7 \\
\hline Armenia & 80.80 & 67 & 2.1 \\
\hline Moldova & 78.00 & 83 & 3.5 \\
\hline Belarus & 76.40 & 89 & 1.8 \\
\hline Ukraine & 75.00 & 101 & 2.5 \\
\hline Azerbaijan & 74.60 & 102 & 5.2 \\
\hline
\end{tabular}

Source: Index of Economic Freedom, Heritage Foundation 2019 [10].

$\mathrm{T}$ The World Bank's Doing Business 2020 particular report on Ukraine tried to answer the simple question of "What does it take to export or import in Ukraine?" According to the country report, exporting a standard container of goods requires eight documents, takes eight days, and costs $\$ 144$ per conditional container. Importing the same container of products requires eight documents, takes seven days, and costs $\$ 169.2$. Globally, Ukraine has ranked 74th out 190 economies on the ease of trading across borders [12]. The rankings for comparator economies and the regional average ranking provide other useful information for assessing how easy it is for a business in Ukraine to export and import goods (Tbl. 5).

As can be seen from Tbl. 5, Belarus became the leading country in terms of trading across borders. Over the last few years, the country has achieved minimalizing the cost of exports and imports, time to export and import, and the number of documents required [13].

\section{CONCLUSIONS}

The main exported products of Ukraine in 2018 are agriculture goods, ores and metals, and manufactured items. The analysis of the commodity structure of exports suggests that Ukraine's exports are diversified. The county exported 3706 types of products to 193 countries.

Georgia's share of the non-resource extractive industry products exceeds $25 \%$ of its exports in 2018 . The main changes at the top of the export basket are a decrease in the volume hazelnuts and increase in that of cigarette and tobacco products for the last two years [14].

Azerbaijan has a very high commodity and country concentration in international trade, especially in export operations. The crude oil and natural gas heavily dominate Azerbaijan's exports, making up $88.5 \%$ of the total exports in 2018. The lack of export diversification is one of the main challenges for Azerbaijan's economy. According to the OECD-WTO report, Azerbaijan has the worst position export diversification in Eastern Europe and Asia [15].

Belarus is a leader concerning ease of cross-border trading and fulfilling documentation requirements and procedures at customs and other regulatory agencies, as well as ease of arranging trade logistics when exporting or importing one standard container. According to the Doing Business 2020, Economy Profile of Belarus, the country ranks the 24th among 190 economies for ease of trading across borders.

A few years before, Georgia was a leading country in terms of cross-border trading, but now this country lags behind Belarus, Moldova, and Armenia.

Cross-border trading with Azerbaijan and Ukraine is much more difficult. Doing Business 2020 reports that Ukraine occupies the 74th place among 190 economies, while Azerbaijan is the 83th. Both countries have more prolonged, more costly procedures, with more documentation required than other Eastern Partnership countries.

Though the Eastern Partnership counties emerged from the former Soviet Union, they have different economic resources and performances. Ukraine is a vast country with diversified export, and a similar situation is characteristic for neighboring Belarus, but the latter has the central planning system. Being small counties, Georgia, Moldova, and Armenia have limited resources. Despite the sustainable economic growth, they all have a significant deficit in international trade and large external debts. Among these counties, only Azerbaijan possesses extensive energy resources but has not succeeded in economic and export diversification.

$\mathrm{F}$ inally, the compared countries have a common challenge: they all could not overcome obstacles they faced in the transition period. The dependence on Russia and periodic political and economic crises are characteristic features of these countries. The next stage of this research study will be focusing on the transition difficulties in terms of economic reforms of the Eastern Partnership counties.

\section{LITERATURE}

1. UNCTAD Trade and Development Report, 2019. URL: https://unctad.org/en/PublicationsLibrary/tdr2019_en.pdf

2. Ukraine Trade Summary Data, World Integrated Trade Solution, 2018. URL: https://wits.worldbank.org/CountryProfile/en/Country/UKR/Year/2018/Summary 
Trading across borders in in Eastern Partnership counties

\begin{tabular}{|c|c|c|c|c|c|c|c|c|c|}
\hline Indicators & 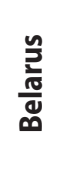 & $\frac{\text { 물 }}{\frac{0}{0}}$ & 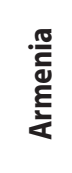 & $\begin{array}{l}\frac{\pi}{5} \\
\text { 웜 }\end{array}$ & 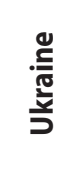 & 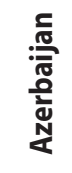 & 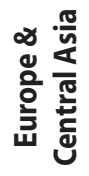 & 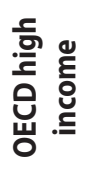 & $\begin{array}{c}\text { Best Regulatory } \\
\text { Performance }\end{array}$ \\
\hline Trading across borders Score & 97 & 92 & 92 & 90 & 80 & 77 & 87.3 & 94.3 & \\
\hline $\begin{array}{l}\text { Time to export Border com- } \\
\text { pliance (hours) }\end{array}$ & 7 & 3 & 27 & 6 & 6 & 17 & 16.1 & 12.7 & 1 (19 Economies) \\
\hline $\begin{array}{l}\text { Cost to export Border } \\
\text { compliance (USD) }\end{array}$ & 65 & 76 & 100 & 112 & 75 & 214 & 150 & 137 & 0 (19 Economies) \\
\hline $\begin{array}{l}\text { Time to export Documen- } \\
\text { tary compliance (hours) }\end{array}$ & 4 & 48 & 2 & 2 & 66 & 33 & 25.1 & 2.3 & 1 (26 Economies) \\
\hline $\begin{array}{l}\text { Cost to export Documentary } \\
\text { compliance (USD) }\end{array}$ & 60 & 44 & 100 & 0 & 192 & 250 & 87.6 & 33.4 & 0 (20 Economies) \\
\hline $\begin{array}{l}\text { Time to import Border } \\
\text { compliance (hours) }\end{array}$ & 0 & 4 & 3 & 15 & 32 & 14 & 20.4 & 8.5 & 1 (25 Economies) \\
\hline $\begin{array}{l}\text { Cost to import Border } \\
\text { compliance (USD) }\end{array}$ & 0 & 83 & 0 & 396 & 100 & 300 & 159 & 98.1 & 0 (28 Economies) \\
\hline $\begin{array}{l}\text { Time to import Documen- } \\
\text { tary compliance (hours) }\end{array}$ & 4 & 2 & 2 & 2 & 48 & 33 & 23.4 & 3.4 & 1 (30 Economies) \\
\hline $\begin{array}{l}\text { Cost to import Documentary } \\
\text { compliance (USD) }\end{array}$ & 0 & 41 & 100 & 189 & 162 & 200 & 85.9 & 23.5 & 0 (30 Economies) \\
\hline
\end{tabular}

Source: Doing Business Index 2020 [12-14].

3. State Statistics Service of Ukraine, Ukraine's Foreign Trade in Goods, 2018. URL: https://ukrstat.org/en/operativ/operativ2018/zd/ztt/ztt_e/ztt1218_e.htm

4. Azerbaijan Trade Summary Data. WITS 2018. URL: https://wits.worldbank.org/CountryProfile/en/Country/AZE/ Year/2018/Summary

5. State Customs Committee of Azerbaijan, Customs Statistics of Foreign Trade 2018. URL: https://customs.gov.az/modules/pdf/pdffolder/71/FILE_7F4BF3-CDDD8A-E1B57A-528F96234D84-EFAB28.pdf

6. Georgia Trade Summary Data. WITS 2018. URL: https://wits.worldbank.org/CountryProfile/en/Country/GEO/ Year/2018/Summary

7. National Statistics Office of Georgia. External Trade of Georgia, 2018. URL: https://www.geostat.ge/media/24973/ External-Merchandise-Trade-2018_publication.pdf

8. Todaro M., Smith S. C. Economic Development. 12th ed. 2015. 862 p. URL: https://mediasrv.aua.gr/eclass/modules/ document/file.php/AOA215/Economic\%20Development $\% 20$ -\%20Todaro\%20and\%20Smith.pdf

9. Why is trade more costly for poor countries? World Bank Blog. URL: http://blogs.worldbank.org/trade/why-istrade-more-costly-for-poor-countries-a-new-database-givesus-some-answers

10. Index of Economic Freedom / The Heritage Foundation. 2019. URL: https://www.heritage.org/index/pdf/2019/ book/index_2019.pdf

11. Free Trade Agreement between Azerbaijan, Armenia, Belarus, Georgia, Moldova, Kazakhstan, Russian Federation, Ukraine, Uzbekistan, Tajikistan and Kyrgyz Republic. URL: https://wits.worldbank.org/GPTAD/PDF/archive/CIS.pdf
12. Doing Business 2020. Economy profile, Ukraine. URL: https://www.doingbusiness.org/content/dam/doingBusiness/ country/u/ukraine/UKR.pdf

13. Doing Business 2020. Economy profile, Belarus. URL: https://www.doingbusiness.org/content/dam/doingBusiness/ country/b/belarus/BLR.pdf

14. Doing Business 2020. Economy profile, Georgia. URL: https://www.doingbusiness.org/content/dam/doingBusiness/ country/g/georgia/GEO.pdf

15. Aid for Trade at a Glance. Economic Diversification and Empowerment. OECD and WTO 2019. P. 137. URL: https://www. oecd.org/aidfortrade/publications/Aid-for-Trade-2019.pdf

\section{REFERENCES}

"Aid for Trade at a Glance. Economic Diversification and Empowerment. OECD and WTO 2019". https://www.oecd.org/ aidfortrade/publications/Aid-for-Trade-2019.pdf

"Azerbaijan Trade Summary Data". WITS 2018. https:// wits.worldbank.org/CountryProfile/en/Country/AZE/Year/2018/ Summary

"Doing Business 2020. Economy profile, Belarus". https://www.doingbusiness.org/content/dam/doingBusiness/ country/b/belarus/BLR.pdf

"Doing Business 2020. Economy profile, Georgia". https://www.doingbusiness.org/content/dam/doingBusiness/ country/g/georgia/GEO.pdf

"Doing Business 2020. Economy profile, Ukraine". https://www.doingbusiness.org/content/dam/doingBusiness/ country/u/ukraine/UKR.pdf

"Free Trade Agreement between Azerbaijan, Armenia, Belarus, Georgia, Moldova, Kazakhstan, Russian Federation, 
Ukraine, Uzbekistan, Tajikistan and Kyrgyz Republic". https://wits. worldbank.org/GPTAD/PDF/archive/CIS.pdf

"Georgia Trade Summary Data". WITS 2018. https://wits. worldbank.org/CountryProfile/en/Country/GEO/Year/2018/ Summary

"Index of Economic Freedom". The Heritage Foundation. 2013. https://www.heritage.org/index/pdf/2013/book/index_2013.pdf

"National Statistics Office of Georgia". External Trade of Georgia, 2018. https://www.geostat.ge/media/24973/ExternalMerchandise-Trade-2018_publication.pdf

"State Statistics Service of Ukraine, Ukraine's Foreign Trade in Goods, 2018". https://ukrstat.org/en/operativ/operativ2018/ zd/ztt/ztt_e/ztt1218_e.htm

"State Customs Committee of Azerbaijan, Customs Statistics of Foreign Trade 2018". https://customs.gov.az/modules/pdf/
pdffolder/71/FILE_7F4BF3-CDDD8A-E1B57A-528F96-234D84EFAB28.pdf

Todaro, M., and Smith, S. C. "Economic Development". 2015. https://mediasrv.aua.gr/eclass/modules/document/file. php/AOA215/Economic\%20Development\%20-\%20Todaro\%20 and\%20Smith.pdf

"UNCTAD Trade and Development Report, 2019". https:// unctad.org/en/PublicationsLibrary/tdr2019_en.pdf

"Ukraine Trade Summary Data, World Integrated Trade Solution, 2018". https://wits.worldbank.org/CountryProfile/en/ Country/UKR/Year/2018/Summary

"Why is trade more costly for poor countries?" World Bank Blog. http://blogs.worldbank.org/trade/why-is-trade-more-costly-for-poor-countries-a-new-database-gives-us-some-answers 